Bangladesh J. Zool. 49 (1): 137-146, 2021

ISSN: 0304-9027

eISSN: $2408-8455$

\title{
ASSESSMENT OF WATER QUALITY OF A TRANSBOUNDARY RIVER AT BRAHMANBARIA
}

\author{
Shova Saha, AHM Shafiullah Habib*, Md. Anichur Rahman and Mallika Saha \\ Department of Zoology, Faculty of Life and Earth Science, Jagannath University, \\ Dhaka, Bangladesh
}

\begin{abstract}
This investigation was undertaken to evaluate some physico-chemical parameter of water of the trans-boundary Haora River in Brahmanbaria during October 2018 to September 2019 from three different sites. The study revealed that air temperature at three different sites ranged $13-38{ }^{\circ} \mathrm{C}$ while the water temperature was $11-32{ }^{\circ} \mathrm{C}$. Transparency of water varied from $18-55 \mathrm{~cm}$ Secchi depth and became more turbid during monsoon. The average values of $\mathrm{pH}$ and dissolved oxygen (DO) both in sites and seasons were within the standard limits for aquatic organisms. Total dissolved solids (TDS) were found between 77 and $352 \mathrm{mg} / \mathrm{L}$ and varied greatly in seasons. Electric conductivity (EC) was ranged 135 to $650 \mu \mathrm{S} / \mathrm{cm}$. On the other hand, maximum and minimum hardness of water were recorded as $322 \mathrm{mg} / \mathrm{L}$ and $118 \mathrm{mg} / \mathrm{L}$ respectively and become lowest in monsoon. The rainy season bear high torrential water which brought huge amount of different types of garbage through the water flow from the Indian part. Most of the garbage are of floating and submerged type as plastic containers, bottles, polybags, cans, etc along with natural debris. During the study period highest $(172 \mathrm{~kg})$ and lowest $(113 \mathrm{~kg})$ plastic garbage were collected in May and July respectively. This foreign garbage may impair the normal healthiness of the river ecology.
\end{abstract}

Key words: Haora River, water quality, garbage

\section{INTRODUCTION}

Bangladesh is blessed with various inland water bodies, which are very rich in diversity of fish species (Banglapaedia, 2012). About 800 rivers with innumerable tributaries flow through the country constituting a waterway of total length around $24,140 \mathrm{~km}$ where it bears a huge potential for fisheries sector (DoF, 2013). But due to over population pressure, unawareness of users, lack of enforcement of legal matters, very few of her water bodies retain good water quality and biodiversity (Alam, 2014). The relationship between food chain, flow of energy and nutrients in aquatic ecosystem is very complex (Odum,

* Author for corresponding: <ahmshabib@gmail.com>

(c)2021 Zoological Society of Bangladesh DOI: https://doi.org/10.3329/bjz.v49i1.53689 
1971). The monitoring of these parameters of a water body is vital for long term and short time study (Wood, 1995). Physical and chemical characteristics of water are important because they impair its quality, distribution and production of fish and other aquatic animals (Swingle, 1969). Besides, distribution and productivity levels of organisms are largely determine by physico-chemical factors (Ashton and Schoeman, 1983). Thus the characteristics of water bodies are very important for the productivity of water. On the other hand, the sources of water pollution may vary but involve almost every significant human activity which includes mostly the dumping of domestic wastes, sewage and untreated industrial effluents into water bodies (Collocott and Dabson, 1974). As a consequence, water quality of river affected adversely.

The Haora is a trans-boundary river, flows through India and Bangladesh which is one of the ten major rivers of Tripura. It is derived from the eastern side of Baramura range, India and flows westerly through the alluvial plains and passes by the southern embankment of the capital city of Agartala before finally flowing down into Bangladesh. In Bangladesh the Haora River entered at the Joynagar village near India-Bangladesh border point and joined with the Titas River at Ujanisar of Akhaura Upazila. The flow length of the river is $53 \mathrm{~km}$ and $10 \mathrm{~km}$ in Indian territory and Bangladesh respectively. In India, river water become polluted due to high anthropogenic interferences as inhabitants on the bank of the river is increasing very fast. As a result, the river water quality has polluted to a risky situation (Tripura State Pollution Control Board, 2004). Moreover it bears huge amount of water with high current along with high amount of garbage to Bangladesh area during the monsoon which is may have adverse effects on the water quality, aquatic organisms and river ecology. So it is inevitable to evaluate the water quality of a trans-boundary river on Haora River. Though the water quality study of the Haora River in Indian part is very few but in Bangladesh part is rare or absent. So, a study was carried out to find out the water quality and status of floating garbage of the Haora River for evaluating the pollution level of water of the said river.

\section{MATERIAL AND METHODS}

Study area: The study was conducted in the Haora River at Akhaura upazila under Brahmanbaria district in Bangladesh. The topography of the area is plain and agricultural land situated near the Bangladesh-Indian border (Joynagar). Three sites of the river were selected for sample collection as entry point at Joynagar (Site 1: 23.823766N, 91.243266E), middle part of the river at Ganganagar (Site 2: 23.832778N, 91.199361E) and the last part of the river where joined with the Titas River at Ujanisar (Site 3: 23.847541N, 91.161766E) (Fig. 1). 

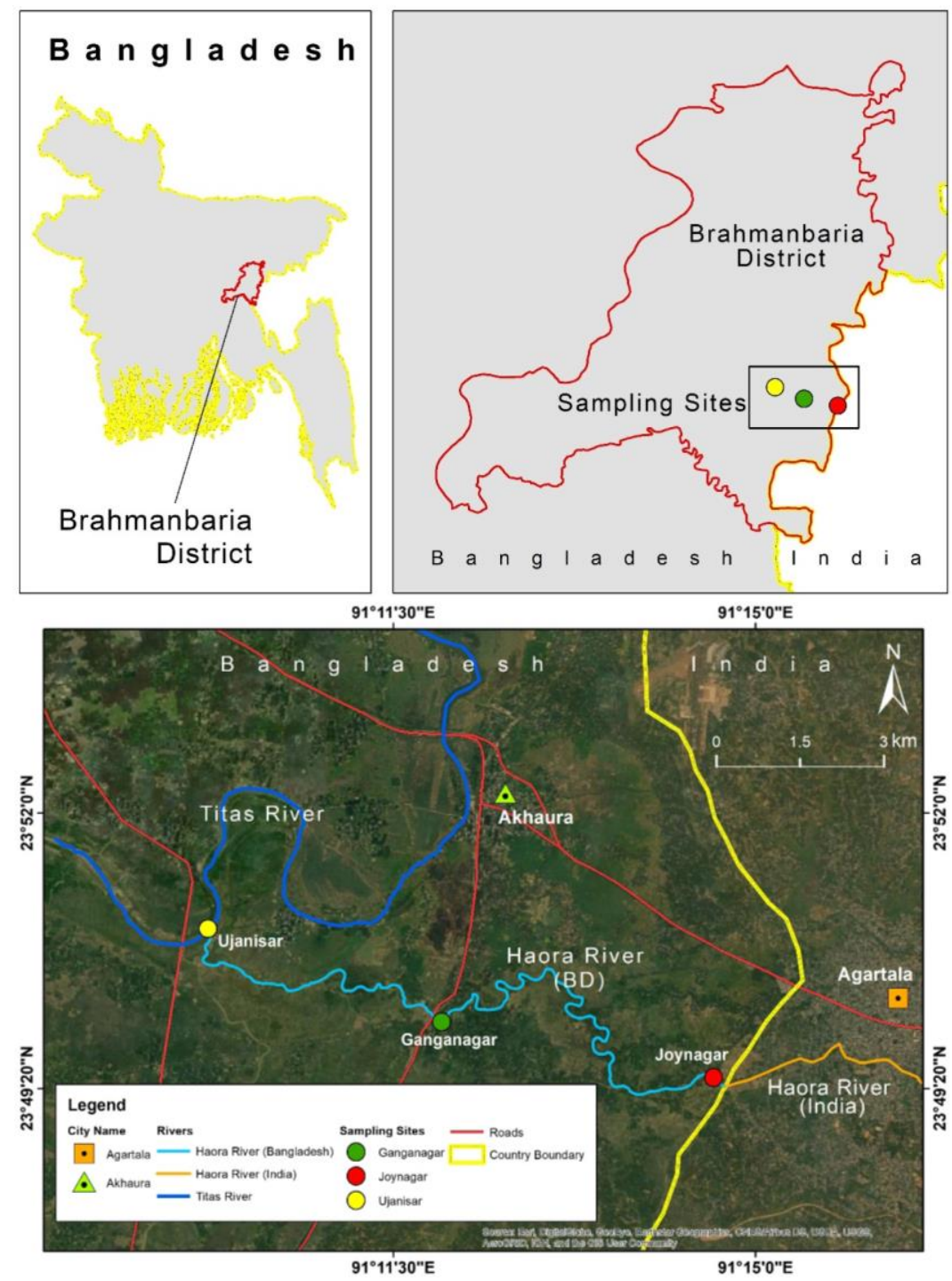

Fig. 1. Three sampling sites of the Haora River in Brahmanbaria.

Data collection and analyses: Water samples were collected once in a month from October 2018 to September 2019. Different seasons of the year were followed as BBS (2015) where three seasons were common viz. summer (March to June), monsoon (July to October) and winter (November to February). The temperature of air and water were determined by using a standard mercury thermometer (Centigrade) directly on spot. The thermometer kept open to the air at sampling sites for 2-3 minutes and recorded the readings. To determine water 
temperature the thermometer was dipped at least $10 \mathrm{~cm}$ into the water for $1-2$ minutes and recorded the reading. Water transparency was measured by a standard $20 \mathrm{~cm}$ diameter Secchi disc, following the technique of Alzaman and Boyd (1978). Transparency was determined by using following formula:

$$
Z s=\left(d_{1}+d_{2}\right) / 2
$$

Where, $Z s$ is the water transparency, $d_{1}$ is the depth where the disc is invisible, and $d_{2}$ is the depth where the disc was visible.

$\mathrm{pH}$ or concentration of hydrogen-ion in water was determined by a $\mathrm{pH}$ meter (Model HANNA, HI-96107) and calibrated using buffer solution which $\mathrm{pH}$ value was 7.0 accordance to standard method before data collection. Dissolved oxygen (DO) was measured with a digital Dissolved Oxygen Meter (Lutron, DO-5509). Total Dissolved Solid (TDS) was measured with a TDS meter (Adwa AD 31, Made in Romania). At the time of measuring TDS, electrical conductivity (EC) is also measured by the same device simply pressing the mode button once and the reading was recorded. Hardness of water was measured by using Ethylenediaminetetraacetic acid (EDTA) solution (HI3812), hardness buffer, calmagite indicator supplied in HANNA Hardness Test Kit (HI 3812). Hardness $(\mathrm{mg} / \mathrm{L})$ was calculated using the following formula as mentioned on the supplied manual:

Hardness of water $=$ Reading of used EDTA solution $\times 300$.

The garbage were collected by the local people with traditional method using rope and net and measured the weight by a digital weight machine at Joynagar point (site 1) in each month when they were available in the water.

\section{RESULTS AND DISCUSSION}

To full fill the objectives of this research evaluating some physic-chemical parameter of river water and impact of garbage flow were carried out round the year and are prevented bellow with their respective heading.

Air temperature: Year long air temperature was recorded from three selected sites of the river showed almost same ranging from 13 to $38{ }^{\circ} \mathrm{C}$. The maximum and minimum annual average air temperatures were recorded $26.42 \pm 2.42{ }^{\circ} \mathrm{C}$ (Site 2) and $25.58 \pm 2.35{ }^{\circ} \mathrm{C}$ (Site 3) respectively (Table 1). On the other hand, highest and lowest average air temperature was recorded as $37.00 \pm 0.58{ }^{\circ} \mathrm{C}$ May and $14.00 \pm 0.58{ }^{\circ} \mathrm{C}$ in May and January respectively (Table 2). Moreover maximum \& minimum seasonal average air temperature was in summer $\left(30.33 \pm 3.54{ }^{\circ} \mathrm{C}\right)$ and winter $\left(18.33 \pm 1.69{ }^{\circ} \mathrm{C}\right)$ respectively (Table. 2). Average air temperature was little bit different among the three sites but average air temperature in winter was varied greatly compare to summer and monsoon. 
Rakiba and Ferdoushi (2013) found average air temperature at six different sites in Dhepa River, Dinajpur ranged between $30.33 \pm 4.16$ to $26.93 \pm 4.87{ }^{\circ} \mathrm{C}$ which is almost similar to the present findings.

Water temperature: Water temperature ranged from $11{ }^{\circ} \mathrm{C}$ to $32{ }^{\circ} \mathrm{C}$ round the year at three selected sites of the river (Table 1). The maximum and minimum annual average water temperatures were recorded $22.58 \pm 1.75{ }^{\circ} \mathrm{C}$ (Site 1) and $20.67 \pm 1.62{ }^{\circ} \mathrm{C}$ (Site 3) respectively (Table 1). On the other hand the-highest and lowest average water temperature was recorded as $30.33 \pm 0.88{ }^{\circ} \mathrm{C}$ and $12.33 \pm 0.88{ }^{\circ} \mathrm{C}$ in July and January respectively (Table 2). Besides, maximum $\&$ minimum seasonal average water temperature was in summer $\left(25.00 \pm 2.46{ }^{\circ} \mathrm{C}\right)$ and winter $\left(16.33 \pm 1.52{ }^{\circ} \mathrm{C}\right)$ respectively (Table. 2). Water temperature in summer was high due to low water level (Salve and Hiware, 2008). Uddin et al. (2013) found average water temperature in the Karnaphuli River $28.6{ }^{\circ} \mathrm{C}$ which is similar to the present findings.

Transparency: Transparency of water varied from $18 \mathrm{~cm}$ to $55 \mathrm{~cm}$ Secchi depths. Maximum and minimum annual average transparency $39.42 \pm 2.75 \mathrm{~cm}$ and $38.33 \pm 2.20 \mathrm{~cm}$ were recorded in the site 2 and site 3 respectively (Table 1). On the other hand, highest average transparency of water of the river was observed $52.30 \pm 1.45 \mathrm{~cm}$ depth in September while the lowest transparency $23.30 \pm 3.53 \mathrm{~cm}$ in April (Table 2). Besides, maximum and minimum seasonal mean transparency of water $46.25 \pm 2.61 \mathrm{~cm}$ and $32.40 \pm 3.58 \mathrm{~cm}$ was in monsoon and summer respectively (Table 2). Water became turbid with onset of monsoon. Hossain et al. (2012) also stated that transparency of the productive fish water ranged from $35-45 \mathrm{~cm}$ is good or ideal. Although transparency of water is species dependent, the river water because of its stream nature remained more turbid during some months in monsoon and found more or less favourable for fish species in most time of the year.

$p H$ : The $\mathrm{pH}$ of the Haora River water ranged from 5.3 to 7.9. The maximum and minimum annual average $\mathrm{pH}$ were recorded $7.24 \pm 0.04$ (Site 3 ) and $7.12 \pm 0.13$ (Site 1) respectively (Table 1). But, the highest and lowest average pH were recorded as $7.73 \pm 0.12$ and $6.20 \pm 0.52$ in November and April respectively (Table 2). What's more, maximum and minimum seasonal average $\mathrm{pH}$ was prevail in winter $(7.37 \pm 0.15)$ and $(6.97 \pm 0.26)$ summer respectively (Table 2$)$. Habib et al. (2013) found at Dhaka-Narayanganj-Demra (DND) dam area water body as maximum $\mathrm{pH} 7.40$ in rainy season and minimum 6.98 in summer, which is supported present findings. Nasar and Munshi (1975) described that the high $\mathrm{pH}$ of water allows growing toxic algal bloom which is turn be harmful to fishes, domestic animals. In terms of $\mathrm{pH}$ condition the Haora River is suitable for aquatic organism. 
Dissolved oxygen (DO): Dissolved oxygen (DO) in the Haora River showed a marked seasonal change which was ranged from 4.2 to $7.8 \mathrm{mg} / \mathrm{L}$. The maximum and minimum annual average DO were recorded $5.62 \pm 0.32 \mathrm{mg} / \mathrm{L}$ (Site 3) and $5.29 \pm 0.29 \mathrm{mg} / \mathrm{L}$ (Site 1) respectively (Table 1). But, thw highest and lowest average DO were recorded as $7.73 \pm 0.12$ and $4.33 \pm 0.08 \mathrm{mg} / \mathrm{L}$ in January and May respectively (Table 2 ). Besides, maximum \& minimum seasonal average DO was in winter $(6.60 \pm 0.47 \mathrm{mg} / \mathrm{L})$ and $(4.85 \pm 0.23 \mathrm{mg} / \mathrm{L})$ summer respectively (Table 2). Cold water can retain more DO, so it found higher in colder months. APHA (1989) recommended above $3.5 \mathrm{mg} / \mathrm{L}$ DO is suitable for fish culture. So, the river water found as liveable for fish.

Total dissolved solid (TDS): Total dissolved solids (TDS) in the river water found a drastic change with the monsoon rain when it reaches its highest point and ranged from 77 to $352 \mathrm{mg} / \mathrm{L}$. The maximum and minimum annual average TDS were $170.59 \pm 34.52 \mathrm{mg} / \mathrm{L}$ (Site 1) and $164.75 \pm 31.12 \mathrm{mg} / \mathrm{L}$ (Site 3) respectively (Table 1). But, the highest and lowest average TDS was recorded as $350.0 \pm 1.16 \mathrm{mg} / \mathrm{L}$ and $79.67 \pm 1.45 \mathrm{mg} / \mathrm{L}$ in April and November respectively (Table 2). Moreover, maximum \& minimum seasonal average TDS was in summer $(312.5 \pm 21.65 \mathrm{mg} / \mathrm{L})$ and $(84.00 \pm 1.65 \mathrm{mg} / \mathrm{L})$ winter respectively (Table 2). According to Tripura State Pollution Control Board (2004) survey report the highest TDS was $110 \mathrm{mg} / \mathrm{L}$ but in the present study the highest TDS was 352 $\mathrm{mg} / \mathrm{L}$ may be due to downstream that opportune the water to mix up with more matters. DoE (1997) recommended TDS concentrations in water is $1000 \mathrm{mg} / \mathrm{L}$. So, the parameter in the river water found within the limit which may not hamper biota.

Electrical conductivity (EC): Like TDS, electric conductivity has great change with season. The value of EC ranged from 135 to $650 \mu \mathrm{S} / \mathrm{cm}$ during the sampling months. The maximum and minimum annual average EC were recorded 287.83 $\pm 54.09 \mu \mathrm{S} / \mathrm{cm}$ (Site 1) and 260.25 $\pm 48.96 \mu \mathrm{S} / \mathrm{cm}$ (Site 3) respectively (Table 1). But, the highest and lowest average EC was recorded as $646.67 \pm 2.40 \mu \mathrm{S} / \mathrm{cm}$ and $139.0 \pm 1.00 \mu \mathrm{S} / \mathrm{cm}$ in April and December respectively (Table 2). Besides, maximum and minimum seasonal average EC was in summer $(493.5 \pm 60.75 \mu \mathrm{S} / \mathrm{cm})$ and $(143.75 \pm 3.70 \mu \mathrm{S} / \mathrm{cm})$ winter respectively (Table 2). High values were recorded during summer might be due to increased concentration of dissolved solids, rapid evaporation and input of sewage. According to Tripura State Pollution Control Board (2004) the highest EC was $210 \mu \mathrm{S} / \mathrm{cm}$ in the Haora River but in the present study in same river found highest $650 \mu \mathrm{S} / \mathrm{cm}$ which was much higher and may be alarming for the living biota of the river. 
Hardness of water: Hardness of water of Haora River ranged from 118 to $322 \mathrm{mg} / \mathrm{L}$ with annual maximum average hardness $255.17 \pm 18.82$ in Site 1 while minimum 247.25 \pm 17.67 in Site 3 (Table 1). On the other hand, April and October showed the highest $(314.67 \pm 4.33 \mathrm{mg} / \mathrm{L})$ and lowest $(119.0 \pm 0.58 \mathrm{mg} / \mathrm{L})$ average value of hardness of water samples (Table 2). Moreover, among the three seasons maximum seasonal average hardness $300.42 \pm 9.76 \mathrm{mg} / \mathrm{L}$ was found in

Table 1. Site-wise annual physico-chemical parameters of the Haora River with APHA (1989) values

\begin{tabular}{|c|c|c|c|c|c|c|}
\hline Parameter & Units & $\begin{array}{l}\text { Maximum- } \\
\text { Minimum- } \\
\text { Mean } \pm \text { SE }\end{array}$ & $\begin{array}{l}\text { Joynagar } \\
\text { (Site 1) }\end{array}$ & $\begin{array}{c}\text { Ganganagar } \\
\text { (Site 2) }\end{array}$ & $\begin{array}{l}\text { Ujanisar } \\
\text { (Site 3) }\end{array}$ & APHA \\
\hline \multirow{4}{*}{$\begin{array}{l}\text { Air } \\
\text { temperature } \\
\text { Water } \\
\text { temperature }\end{array}$} & \multirow[t]{2}{*}{$\left({ }^{\circ} \mathrm{C}\right)$} & Max-Min & $38-15$ & $38-14$ & $36-13$ & \multirow[t]{2}{*}{-} \\
\hline & & Mean $\pm S E$ & $26.17 \pm 2.24$ & $26.42 \pm 2.42$ & $25.58 \pm 2.35$ & \\
\hline & \multirow[t]{2}{*}{$\left({ }^{\circ} \mathrm{C}\right)$} & Max-Min & $32-14$ & $31-12$ & $29-11$ & \multirow{2}{*}{$\begin{array}{l}\text { Species } \\
\text { dependent }\end{array}$} \\
\hline & & Mean $\pm S E$ & $22.58 \pm 1.75$ & $21.83 \pm 1.72$ & $20.67 \pm 1.62$ & \\
\hline Transparenc & \multirow[t]{4}{*}{$(\mathrm{cm})$} & Max-Min & $50-18$ & $55-22$ & $52-28$ & \multirow{4}{*}{$\begin{array}{l}\text { Species } \\
\text { dependent } \\
\text { Species } \\
\text { dependent }\end{array}$} \\
\hline y & & Mean \pm SE & $38.42 \pm 2.27$ & $39.42 \pm 2.75$ & $38.33 \pm 2.20$ & \\
\hline \multirow[t]{2}{*}{$\mathrm{pH}$} & & Max-Min & $7.9-6.2$ & $7.9-5.3$ & $7.5-7.1$ & \\
\hline & & Mean \pm SE & $7.12 \pm 0.13$ & $7.13 \pm 0.20$ & $7.24 \pm 0.04$ & \\
\hline \multirow[t]{2}{*}{ DO } & \multirow[t]{2}{*}{ (mg/L) } & Max-Min & $7.2-4.4$ & 7.3-4.3 & $7.8-4.2$ & \multirow[t]{2}{*}{$>3.5$} \\
\hline & & Mean $\pm S E$ & $5.29 \pm 0.29$ & $5.55 \pm 0.29$ & $5.62 \pm 0.32$ & \\
\hline \multirow[t]{2}{*}{ TDS } & \multirow[t]{2}{*}{ (mg/L) } & Max-Min & $350-77$ & $352-80$ & $348-82$ & \multirow[t]{2}{*}{-} \\
\hline & & Mean $\pm S E$ & $170.59 \pm 34.52$ & $165.67 \pm 31.81$ & $164.75 \pm 31.12$ & \\
\hline \multirow[t]{2}{*}{ EC } & \multirow[t]{2}{*}{$(\mu \mathrm{S} / \mathrm{cm})$} & Max-Min & $650-140$ & $648-135$ & $642-138$ & \multirow[t]{2}{*}{-} \\
\hline & & Mean \pm SE & $287.83 \pm 54.09$ & $274 \pm 52.23$ & $260.25 \pm 48.96$ & \\
\hline \multirow[t]{2}{*}{ Hardness } & \multirow[t]{2}{*}{ (mg/L) } & Max-Min & $322-120$ & $315-118$ & $307-119$ & \multirow[t]{2}{*}{$>34.9$} \\
\hline & & Mean \pm SE & $255.17 \pm 18.82$ & $249.831 \pm 9.09$ & $247.25 \pm 17.67$ & \\
\hline
\end{tabular}

summer. However minimum $175.25 \pm 22.73 \mathrm{mg} / \mathrm{L}$ was observed in monsoon (Table 2). Rain water probably decreases the hardness of water. Hujare (2008) reported total hardness was high during summer than monsoon and winter. High value of hardness during summer can be attributed to decrease in water volume and increase of rate of evaporation of water. According to Tripura State Pollution Control Board (2004) the highest hardness was $107.8 \mathrm{mg} / \mathrm{L}$ but in the present study the highest hardness was $322 \mathrm{mg} / \mathrm{L}$ which was much higher. The hardness of water increases gradually which may have bad impact on the living organisms of the river.

Garbage flow through Haora River: It was observed that the Haora River bears significant amount of different types of garbage through the water flow from the Indian part. Various types of garbage were found in Joynagar point (site 1), the entry point of the river into Bangladesh. During the study period, maximum $172 \mathrm{~kg}$ of waste matters was recorded in May as became of lowest water current. However, $113 \mathrm{~kg}$ in July as water current was higher due to rainy season (Fig. 3). Local villagers could collect as high as $172 \mathrm{~kg}$ of waste matters 
Table 2. Annual average values of water parameters three sites of the Haora River

\begin{tabular}{|c|c|c|c|c|c|c|c|c|c|}
\hline \multirow[t]{2}{*}{ Season } & \multirow{2}{*}{$\begin{array}{c}\text { Month } \\
\text { s }\end{array}$} & \multicolumn{2}{|c|}{ Temperature $\left({ }^{\circ} \mathrm{C}\right)$} & \multirow{2}{*}{$\begin{array}{c}\text { Transpare } \\
\text { ncy }(\mathbf{c m})\end{array}$} & \multirow[t]{2}{*}{$\mathrm{pH}$} & \multirow{2}{*}{$\begin{array}{r}\begin{array}{r}\text { DO } \\
(\mathrm{mg} / \mathrm{L})\end{array}\end{array}$} & \multirow{2}{*}{$\begin{array}{c}\text { TDS } \\
(\mathrm{mg} / \mathrm{L})\end{array}$} & \multirow{2}{*}{$\begin{array}{c}\mathbf{E C} \\
(\mu \mathrm{S} / \mathrm{cm})\end{array}$} & \multirow{2}{*}{$\begin{array}{c}\text { Hardness } \\
(\mathrm{mg} / \mathrm{L})\end{array}$} \\
\hline & & Air & Water & & & & & & \\
\hline \multirow{3}{*}{ Summer } & Mar'19 & $27.00 \pm 1.53$ & $22.00 \pm 1.53$ & $35.70 \pm 2.33$ & $7.13 \pm 0.03$ & $5.43 \pm 0.19$ & $325.0 \pm 1.53$ & $359.33 \pm 31.6$ & $271.67 \pm 4.41$ \\
\hline & Apr 19 & $22.00 \pm 0.58$ & $19.67 \pm 0.88$ & $23.30 \pm 3.53$ & $6.20 \pm 0.52$ & $4.77 \pm 0.08$ & $350.0 \pm 1.16$ & $646.67 \pm 2.40$ & $314.67 \pm 4.33$ \\
\hline & $\begin{array}{l}\text { May'19 } \\
\text { Jun'19 }\end{array}$ & $\begin{array}{l}37.00 \pm 0.58 \\
35.33 \pm 0.88\end{array}$ & $\begin{array}{l}28.67 \pm 0.88 \\
29.67 \pm 0.88\end{array}$ & $\begin{array}{l}40.00 \pm 1.16 \\
30.70 \pm 1.76\end{array}$ & $\begin{array}{l}7.23 \pm 0.09 \\
7.30 \pm 0.06\end{array}$ & $\begin{array}{l}4.33 \pm 0.08 \\
4.87 \pm 0.08\end{array}$ & $\begin{array}{c}250.0 \pm 35.47 \\
325.0 \pm 1.73\end{array}$ & $\begin{array}{l}447.67 \pm 55.0 \\
520.33 \pm 4.18\end{array}$ & $\begin{array}{l}305.67 \pm 6.33 \\
309.67 \pm 2.40\end{array}$ \\
\hline \multirow[t]{2}{*}{ Average } & & $30.33 \pm 3.54$ & $25.00 \pm 2.46$ & $32.42 \pm 3.58$ & $6.97 \pm 0.26$ & $4.85 \pm 0.23$ & $312.5 \pm 21.65$ & $493.5 \pm 60.75$ & $300.42 \pm 9.76$ \\
\hline & Jul' 19 & $36.33 \pm 0.88$ & $30.33 \pm 0.88$ & $44.70 \pm 1.45$ & $7.17 \pm 0.19$ & $4.73 \pm 0.15$ & $155.33 \pm 2.60$ & $271.67 \pm 0.88$ & $171.67 \pm 4.41$ \\
\hline \multirow[t]{2}{*}{ Monsoon } & Aug'19 & $35.33 \pm 0.33$ & $26.33 \pm 0.88$ & $48.00 \pm 1.16$ & $7.03 \pm 0.12$ & $5.33 \pm 0.33$ & $94.33 \pm 2.19$ & $172.67 \pm 3.93$ & $230.0 \pm 5.77$ \\
\hline & $\begin{array}{l}\text { Sep'19 } 19 \\
\text { Oct'18 }\end{array}$ & $\begin{array}{l}23.67 \pm 0.88 \\
22.67 \pm 0.88\end{array}$ & $\begin{array}{l}19.33 \pm 0.88 \\
19.00 \pm 0.58\end{array}$ & $\begin{array}{l}52.30 \pm 1.45 \\
40.00 \pm 4.62\end{array}$ & $\begin{array}{l}6.83 \pm 0.18 \\
7.70 \pm 0.15\end{array}$ & $\begin{array}{l}5.17 \pm 0.32 \\
4.80 \pm 0.06\end{array}$ & $\begin{array}{l}86.67 \pm 0.88 \\
81.67 \pm 2.40\end{array}$ & $\begin{array}{l}147.67 \pm 1.45 \\
147.33 \pm 3.71\end{array}$ & $\begin{array}{c}180.33 \pm 8.11 \\
119.0 \pm 0.58\end{array}$ \\
\hline \multirow[t]{2}{*}{ Average } & & $29.5 \pm 3.67$ & $23.75 \pm 2.78$ & $46.25 \pm 2.61$ & $7.18 \pm 0.19$ & $5.01 \pm 0.14$ & $104.5 \pm 17.14$ & $184.83 \pm 29.5$ & $175.25 \pm 22.73$ \\
\hline & Nov' 18 & $21.33 \pm 0.88$ & $18.33 \pm 0.88$ & $37.30 \pm 1.45$ & $7.73 \pm 0.12$ & $5.30 \pm 0.45$ & $79.67 \pm 1.45$ & $141.67 \pm 4.41$ & $291.0 \pm 2.08$ \\
\hline \multirow[t]{3}{*}{ Winter } & Dec'18 & $20.67 \pm 0.88$ & $19.00 \pm 1.16$ & $37.70 \pm 1.45$ & $7.50 \pm 0.17$ & $6.47 \pm 0.15$ & $84.00 \pm 3.06$ & $139.00 \pm 1.00$ & $283.0 \pm 3.06$ \\
\hline & Jan'19 & $14.00 \pm 0.58$ & $12.33 \pm 0.88$ & $33.30 \pm 3.53$ & $7.23 \pm 0.03$ & $7.43 \pm 0.19$ & $84.67 \pm 1.45$ & $139.33 \pm 0.67$ & $235.67 \pm 2.33$ \\
\hline & Feb'19 & $17.33 \pm 0.33$ & $15.67 \pm 0.33$ & $41.80 \pm 0.33$ & $7.03 \pm 0.07$ & $7.20 \pm 0.06$ & $87.67 \pm 1.45$ & $155.0 \pm 2.52$ & $296.67 \pm 3.53$ \\
\hline Average & & $18.33 \pm 1.69$ & $16.33 \pm 1.52$ & $37.5 \pm 1.70$ & $7.37 \pm 0.15$ & $6.60 \pm 0.47$ & $84.00 \pm 1.65$ & $143.75 \pm 3.70$ & $276.58 \pm 13.9$ \\
\hline
\end{tabular}

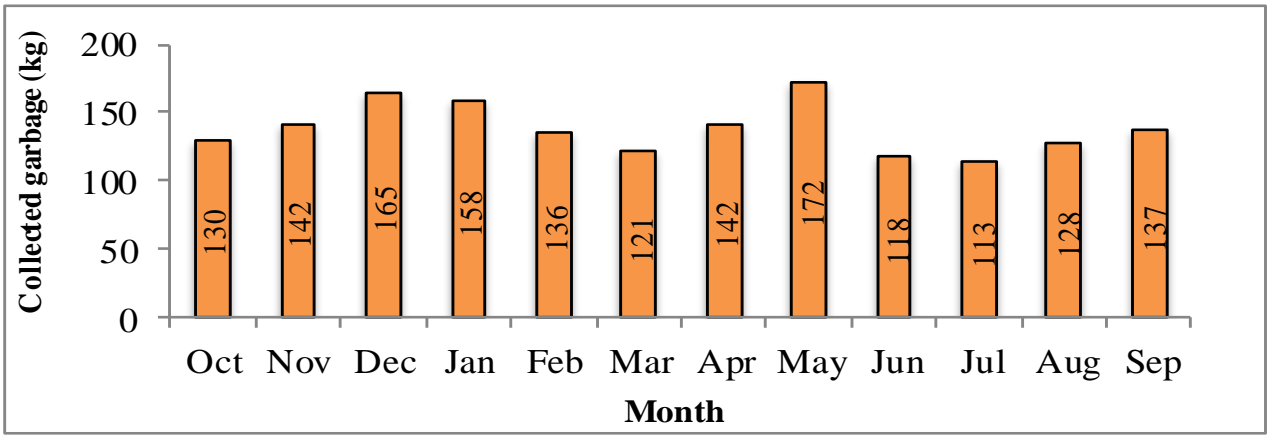

Fig. 3. Monthly garbage $(\mathrm{kg})$ flow in the Haora River, at Joynagar point (site 1).

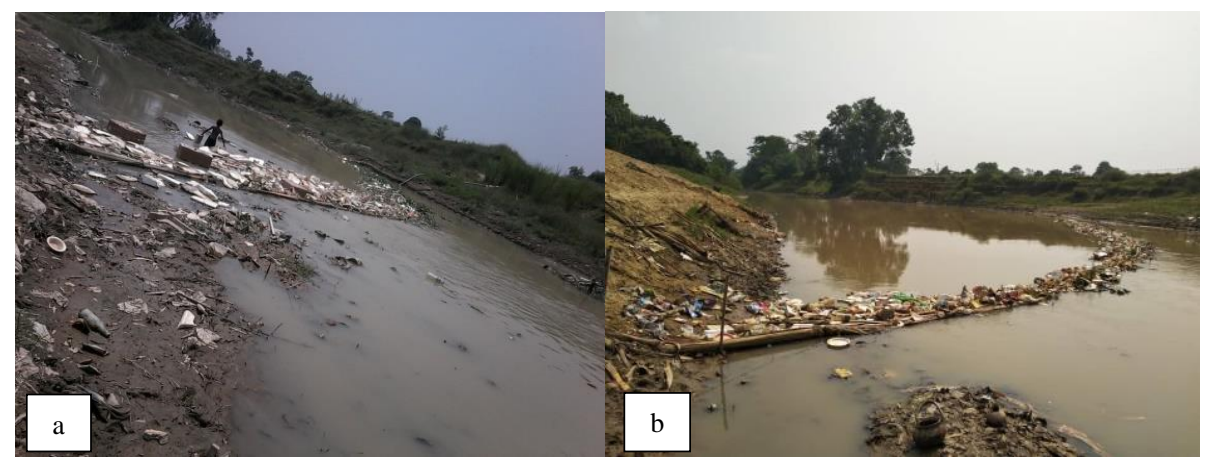

Fig. 4. Garbage flow in the Haora River (a) summer and (b) winter at Joynagar point (site 1).

mostly floating types in May because that time water current was slow and lowest $113 \mathrm{~kg}$ in the month of July because that time water current was high 
(Fig. 3). Garbage includes plastic bags, plastic bottle of different types of beverages, medicine bottles, wine bottles, polythene, one time plates, one time glasses, cloths, pants, brushes, rubbish clothes, different types of broken plastic products, shoes, different types of waste matters, cans which are made of aluminium and tin or other metals. It was found that at Joynagar point some local people collect a part of this garbage with rope and net for selling them after sorting (Fig. 4). But they could not collect all garbage product for high water current of the Haora River especially in the monsoon. They could only collect floating type garbage approximately one fourth of total flowing through the river and the rest floating, submerged and sunk parts were freely entered in the Bangladesh territory. Those which were unable to collect mixed with the water of the Titas River. This river finally supply to the Meghna River system which may hamper the river ecology and adjacent area. These harmful garbage might be alarming for our environment especially the land and aquatic biota along with the healthiness of the ecosystem of the river and near land area.

\section{CONCLUSION}

Physico-chemical of the water in the Haora River change with time. The overall condition of water fluctuating because of radical change in the flow of water which is subject to over rain especially hamper when the river over flow with much water carried from India part. The most alarming thing should be noted that the river carry much debris of plastic bottles, cans, garbage that are the wastes of India. This should be great challenge for Bangladesh to maintain the normal condition of the river.

\section{LITERATURE CITED}

ALAM, M. S. 2014. Assessment of water Quality of Hatirjheel Lake in Dhaka City. International Journal of Technology Enhancements and Emerging Engineering Research. 2(6): 97-100.

ALZAMAN, G. and BOYD, C. E. 1978. An evaluation Secchi disc visibility for estimating plankton density in fish ponds. Hydrobiology. 65: 601-608.

APHA-AWWA-WPCF, 1989. Standard methods for the examination of water and wastewater. New York: American Public Health Association.

ASHTON, P.J. and SCHOEMAN, F.R. 1983. Limnological studies on the pretoria salt pan, Hyper saline Maar lake. Hydrobiologia. 99: 61-73.

BANGLAPEDIA, 2012. Asiatic society of Bangladesh. 1st Edn., National Encyclopaedia of Bangladesh, February 2012, Dhaka, Bangladesh.

BBS, 2015. Annual Report 2015, Bangladesh Bureau of Statistics, Ministry of Planning.

COLLOCOTT, T. C. and DABSON, A. 1974. Chambers Science and Technology dictionary chambers Edinburgh. p. 56. 
DoE, 1997. Standards for Water. Schedule 3, Ministry of Forestry and Environment, Government of Bangladesh. The Environment Conservation Rules.

DoF, 2013. National fish week 2013 Compendium. Department of Fisheries, Ministry of Fisheries and Livestock, Government of the People's Republic of Bangladesh, pp. 1-144.

HABIB, A.H.M.S., ALAM, M.M. and NASER, M.N. 2013. Suitability of the west led DhakaNarayanganj-Demra (DND) dam canal for water aquaculture practices. Jagannath University Journal of Science. 2(1): 33-38.

HOSSAIN, A. M. I., ADHIKARY, S. K. and ELAHI, M. M. A. 2012. Assessment of shallow ground water quality from six wards of Khulna City Corporation, Bangladesh. International journal of Applied Science and Engineering Research. 1(3): 488-498.

HUJARE, M. S. 2008. Seasonal variation of physico-chemical parameters in the perennial tank of Talsande, Maharashtra. Ecotoxicol. Environ. Monitor. 18(3): 233-242.

NASAR, S. A. K. and MUNSHI, J. S. D. 1975, Studies on the primary production of freshwater pond. Jap. J. Ecol. 55: 21-23.

ODUM, E. P. 1971. Fundamentals of Ecology W.B. Saunders Co. Philadelphia. pp. 574-592.

RAKIBA, K. and FERDOUSHI, Z. 2013. Physico-chemical properties of Dhepa River in Dinajpur District of Bangladesh. J. Environ. Sci. \& Natural Resources. 6(1): 59-67.

SALVE, V.B. and HIWARE, C. J. 2008. Study on water quality of Wanparakalpa reservoir Nagpur, Near Parli Vaijnath, District Beed. Marathwada region. J. Aqua. Biol. 21(2): 113-117.

SWINGLE, H.S. 1969. Method of analysis for waters, organic matter and pond bottom solids used in fisheries research. Auburn University, Auburn, Alabama. p. 119.

TRIPURA STATE POLLUTION CONTROL BOARD, 2004. Pollution Status Assessment of Haora River, Tripura, Government of India.

Uddin, M. R., Hossain, M.M., Akter, S., Ali, M.E. and Ahsan, M.A., 2020. Assessment of some physicochemical parameters and determining the corrosive characteristics of the Karnaphuli estuarine water, Chittagong, Bangladesh, Water Science, 34(1), 164-180, DOI: $10.1080 / 11104929.2020 .1803662$

WOOD, A. 1995. Constructed wetland in water pollution control fundamental to their understanding. Water Science and Technology. 32: 21 